\title{
A Primer on Exporting to Costa Rica 1
}

\author{
Christina D. Storz, Timothy G. Taylor, and Gary F. Fairchild ${ }^{2}$
}

\section{Introduction}

Every year the U.S. Department of State publishes extensive Country Commercial Guides for a large number of countries. These guides provide a great deal of information useful to individuals interested in developing export markets either through direct exports or through direct foreign investment. This paper provides an abridged version of the Country Commercial Guide for Costa Rica as well as supplemental information of direct relevance to agribusiness firms. It is hoped that the information contained in this report provides a useful starting point for individuals interested in exploring export or investment opportunities in Costa Rica.

Note: County Commercial Guides are available for U.S. exporters from the National Trade Data Bank's CD-ROM or via the Internet. Please contact Stat-USA by telephone (1-800) STAT-USA for more information. Country Commercial Guides can be accessed via the World Wide Web at http://www.stat-usa.gov, http://www.state.gov, and http://www.mac.doc.gov. They can also be ordered as a hard copy or on diskette from the National Technical Information Service (NTIS) by telephone (1-800) 553-NTIS. American exporters seeking general export information/assistance and country-specific commercial information should contact the U.S. Department of Commerce, Trade Information Center by telephone (1-800) USA-TRADE; or by fax (202) 482-4473.

\section{Economic and Political Overview}

The United States is Costa Rica's most important commercial and agricultural partner. Costa Ricans welcome U.S. technology, products, and services due to the close geographical proximity of the two countries and the high quality and wide selection of competitively priced products. The Costa Rican political system is a long-standing, constitutional democracy, regarded as the most stable in Central America. The United States and Costa Rica enjoy an excellent bilateral relationship. In 2002, Costa Rica ranked 32nd as a market for U.S. exports and early indications for 2003 show it has improved to 29 th place.

Costa Rica's relatively well-educated and productive work force, favorable tax and duties regime in free trade zones, and central location in the hemisphere attract investors. However, its ranking is declining according the 2003-2004 World Economic Forum (WEF) Global Competitiveness report. The report attributes the deterioration to Costa Rica's macroeconomic problems and the relative difficulties

1. This is EDIS document FE509, a publication of the Department of Food and Resource Economics, Florida Cooperative Extension Service, Institute of Food and Agricultural Sciences, University of Florida, Gainesville, FL. Published February 2005. Please visit the EDIS website at http://edis.ifas.ufl.edu.

2. Christina D. Storz, Research Assistant; Timothy G. Taylor, Professor; and Gary F. Fairchild, Professor, Department of Food and Resource Economics, Florida Cooperative Extension Service, Institute of Food and Agricultural Sciences, University of Florida, Gainesville, FL. 
in doing business locally. The lack of a political foundation for foreign investment in restricted sectors raises real risks for potential investors.

In 2002, Costa Rica's GDP (Gross Domestic Product) growth was $2.8 \%$, nearly three times the 2001 growth rate. Estimates for GDP growth in 2003 and 2004 are $2.7 \%$ and $3.5 \%$, respectively. Expected inflation for 2003 is $10 \%$ and $11 \%$ for 2004 . Foreign direct investment (FDI) in Costa Rica was concentrated in the industrial and tourism sectors in 2002 and totaled US\$627 million, up from US\$448 million in 2001. In 2002, FDI from U.S. companies amounted to US\$214 million, equivalent to $34.9 \%$ of FDI and topped only by the one-time purchase of the local brewery stock for US $\$ 230$ million by a Dutch company.

The growing fiscal deficit continues to be one of Costa Rica's most serious macroeconomic problems. The government's fiscal deficit target for 2003 is $3.1 \%$ of GDP. In April of 2003, the three leading international bond-rating agencies downgraded Costa Rica's sovereign credit rating to "negative". All three agencies cited fiscal deficits as a concern and two noted the increase in dollar-denominated credit as worrisome.

Costa Rica's export revenue in 2002 increased $4.6 \%$ to US\$5,252 million. Exports to the United States grew $4.8 \%$ to US $\$ 2,782$ million, an increase of $4.8 \%$ during 2002 . Imports grew $9.2 \%$ to US\% 7,175 million in 2002. Rising imports and declining exports caused Costa Rica's trade deficit in goods to rise to a record US $\$ 1,922$ million in 2002, from US $\$ 1,547$ million in 2001. Despite a growing foreign trade deficit, the growth of exports during 2002 was a marked improvement from 2001. Industrial exports, fish and other seafood, and Free Trade Zone exports grew significantly. Among traditional exports, banana and coffee revenues grew slightly despite continued low world prices. Sugar and beef export revenues declined in 2002.

In January of 2003, the United States began negotiating a U.S.-Central America Free Trade Agreement (known as CAFTA) with Guatemala, El Salvador, Honduras, Nicaragua, and Costa Rica. Costa Rica has also signed free trade agreements with
Mexico, Chile, Canada, and the Dominican Republic.

Companies frequently cite difficulties working with government bureaucracy and regulatory agencies as a negative factor in doing business in Costa Rica. American companies possessing contracts with the Costa Rican government sometimes face difficulties because constitutional and legal challenges can disrupt execution of contracts. Costa Rica has one of the highest levels of English competency in Latin America, but the recent wave of new investments by high technology companies, call centers, and business services centers has taxed the country's ability to meet new foreign investors' demand for English-speaking professionals. Some companies cite problems with the cost and quality of telecommunications services provided by Instituto Costarricense de Electricidad (ICE), the state telecommunications monopoly. Many companies in Costa Rica complain about the quality of the country's telecommunications services.

\section{Marketing U.S. Products and Services}

There are a number of factors that should be considered in exporting products to Costa Rica. This section provides a brief overview of many critical factors that must be considered.

\section{Establishing a Business}

The first step in establishing a business in Costa Rica is to obtain the assistance of a Public Notary, the only professional authorized by law to register a company in Costa Rica. Companies must be filed in the Costa Rican Mercantile Registry to be legal, authorized entities. At registration, all information related to the new company and the persons who will manage the company must be submitted. An extract of the registration is then published in "La Gaceta" (the official legal journal). Payment on initial equity (usually nominal) must be expressed in local currency and deposited with a local bank of the Costa Rican national banking system until registration is completed. 
Individuals interested in establishing a business in Costa Rica are encouraged to contact Costa Rican Coalition for Development Initiatives (CINDE) and/or the Costa Rican Foreign Trade Corporation. Both organizations are involved in providing support and information for prospective investors to Costa Rica.

\section{Distribution / Sales Channels}

Costa Rica is affectionately referred to as "Latin America Lite" because of the abundance of U.S. products and services that gives the country the feeling of being in America. The retail distribution sector closely follows U.S. practices. Seventy-five percent ( 2.5 million people) of the consumers live in the Greater San Jose area (also known as The Central Valley).

Distribution channels do not vary significantly for food/agricultural products. Some products (e.g., fresh fruits and frozen foods) require technical handling knowledge due to their shelf life requirements and need for refrigeration. Such facilities are available in Costa Rica since it exports to other Central American and Caribbean countries. Private firms import consumer foods and there are several wholesalers dedicated to the food import business. The food product distribution chain to supermarkets and to medium and small stores is well developed. Some of the larger supermarket chains import directly.

\section{Agents / Distributors: Finding a Partner}

A representative or a distributor is any individual or company who "in continuous and autonomous form, with and without legal representation, acts by directly placing purchase of sales orders among the local import or export firms, on a commission or percentage basis; or who prepares, promotes, facilitates, and completes the sale of merchandise or services which another foreign merchant or firm renders."

A distributor must also meet the same requirements as a representative, as described above. Specifically, a distributor is an individual or company purchasing goods directly from the manufacturer for the purpose of resale. Generally, a distributor signs a distribution agreement with the manufacturer and carries a stock of inventory. A distribution agreement may be exclusive or non-exclusive. It is not uncommon to find a representative or a distributor representing multiple product lines. The Commercial Service offers U.S. companies assistance in identifying potential business opportunities in Costa Rica.

The Commercial Service offers its worldwide Gold Key Service (GKS) for those who wish to travel to Costa Rica and its International Partner (IPS) search for those companies who cannot immediately visit Costa Rica. These services assist U.S. companies in locating an appropriate representative. To request either service, U.S. firms should e-mail San.JoseCR.office.box@mail.doc.gov.

\section{Performing Due Diligence}

Before finalizing any contract, whether for a sale or representation, U.S. companies are urged to obtain information on the bona fides of the foreign firm, including reliable business and financial references. The U.S. Department of Commerce offers a service known as an International Company Profile (ICP).The ICP is a confidential report on a foreign firm that provides a commercial and financial profile, including business and financial references. Well-known private sector credit-reporting services also provide credit reports in Costa Rica and the Commercial Section can provide contact information to interested firms.

\section{Direct Marketing}

Direct marketing has enjoyed limited success in Costa Rica. Since the country does not have a postal/mailing system with defined street names and numbers, it is difficult to obtain client lists or reliable addresses.

\section{Franchising}

The current growth of franchising is slowing due to saturation, mostly in the fast food sector. It is estimated that less than $20 \%$ of franchises are locally owned, and the remaining $80 \%$ are foreign-owned (of this percentage, $90 \%$ are U.S. franchises). A key success factor for franchisers in the Costa Rican 
market is careful selection of the potential franchisee and location of the outlet. Franchise royalties are taxed a $25 \%$ withholding tax, but the United States does give a foreign tax credit for this expense. Import taxes vary as to the item; the trend is toward lower import taxes.

\section{Joint Ventures / Licensing}

Licensing is not widespread in Costa Rica.

\section{Selling Factors / Techniques}

As in the United States, purchase decisions by Costa Ricans generally are based on price, quality, technical specifications, convenience, and the availability of local product support or after sales service. The Costa Rican government does not determine product prices. American exporters to Costa Rica must be willing to make smaller sales than those to which they may be accustomed in larger markets. Or, better yet, Costa Rica should be viewed in the context of the larger region of Central America.

\section{Advertising / Trade Promotion}

Costa Rican newspapers are amongst the best ways to promote sales of products or services. Depending on the target market, advertising is also effective in magazines produced by organizations such as the Costa Rican-American Chamber of Commerce (AmCham), the Chamber of Commerce of Costa Rica, and other specialized chambers/business associations.

In addition to the U.S. Department of Commerce export promotion programs, the Commercial Service in San Jose can assist U.S. firms through trade missions, local trade shows, matchmaker events, seminars, conferences, catalog shows, and business receptions. Also, the private trade fair organizer, FERCORI, has at least one international trade fair every year.

\section{Sales Service / Customer Support}

Product support and after-sales service, usually provided through a local representative with the support of the U.S. exporter, is extremely important for both Costa Rican government institutions and private purchasers.
Availability of maintenance contracts, identification of convenient repair facilities, and required technical support are expected by buyers. Service literature and contracts should be provided in Spanish. The proximity of the United States to Costa Rica provides U.S. exporters with added flexibility in determining the most cost-effective and efficient product support arrangements.

\section{Product Pricing}

Prices of products imported into Costa Rica are typically based on the CIF value plus import taxes, Customs agent fees, in-country transportation costs, and other product-related costs. U.S. export pricing generally excludes the U.S. domestic marketing cost component, allowing a base price that is more competitive while maintaining attractive pricing in the market. Virtually all companies price their goods in dollars.

\section{Selling to the Government}

The Costa Rican Financial Administration Law governs the Costa Rican government procurement system. Government entities generally acquire their goods and services through public tenders, which are published in the official newspaper (La Gaceta) and major newspapers. Some purchases are made directly from suppliers that have pre-qualified and pre-registered with government entities.

Foreign companies may establish a representative through a Power of Attorney for a specific tender. This representative can be a Costa Rican citizen/company, alien, or resident of the country. A general Power of Attorney can also be given to an individual or company to represent the foreign company in various tenders for a specified period of time. The local representative should be able to translate tender documents from Spanish into English and assist in preparing bid offers in Spanish. Some large projects may require the presence of U.S. company officials in Costa Rica to better evaluate the requirements and prepare a competitive offer to the Costa Rican government entity. 


\section{IPR Infringement Protection}

Legislation was passed in January of 2000 to bring Costa Rica's patent regime into compliance with World Trade Organization (WTO) standards. To ensure maximum IPR (intellectual property rights) protection for any valuable product, it is advisable to obtain the services of an experienced intellectual property attorney familiar with local IPR laws and with the procedures of the Costa Rican National Registry.

\section{Need for a Local Attorney}

Obtaining competent local legal representation is critical when planning to start a business, buy or sell real estate, apply for resident status, or make any type of significant investment in Costa Rica.

Not only is Costa Rica's legal system (based on Roman law) considerably different than that of the United States (based on English common law), but also language differences present opportunities for serious miscommunications and misunderstandings, sometimes with fatal consequences. It is strongly advisable to retain the services of an attorney who is completely bilingual to avoid potential communication failures.

\section{Agribusiness Industry Prospects}

The United States is the single most important agricultural partner of Costa Rica due to its geographical proximity and to its high quality, wide selection of competitively priced products. Costa Rica negotiated a free trade agreement with Chile, which became effective in February of 2002. Under the agreement, Chilean fruits (fresh and canned), candies, and other food products will receive preferential treatment, resulting in stronger competition for U.S. products. Costa Rica also negotiated a free trade agreement with Canada, which took effect in November of 2002. The agreement provides duty-free access to agricultural products competing with U.S. products, primarily fruits.

Most grains are imported in bulk, limiting the import market to a few major players. There are two wheat mills (Molinos de Costa Rica and Fábrica de Harinas de Centroamerica), which account for all wheat imports. Two groups of private sector importers make almost all yellow corn and soybean import purchases. Rice is generally imported by a group of producers and millers associated under the name Corporacion Arrocera. Rice importers outside of this group have to pay higher duties and face non-tariff barriers.

Since December of 1994, no import permits (other than phytosanitary and sanitary) are required for imports of grains, poultry, meat, dairy products, or any other agricultural product per the terms of Costa Rica's General Agreement on Tariffs and Trade (GATT) accession agreement.

Costa Rica finally established tariff-rate quotas (TRQs) for high tariff products in conformance with its Uruguay Round commitments in July of 1997. The TRQs for chicken parts were partially filled in 1998, 1999, and 2000. Although there was interest on the part of importers in using the chicken TRQs in 2001 and 2002, Costa Rica banned poultry imports from the United States in January of 2001. After substantial government-to-government negotiations and inspections of U.S. and Costa Rican processing plants the ban was lifted in 2002. Outside of the TRQs, Costa Rica also reduced tariffs on these sensitive products from $266 \%$ to $150 \%$ for chicken and from $106 \%$ to $65 \%$ for dairy products.

A list of the most important Costa Rican importers of consumer-oriented foods can be obtained by contacting the U.S. Department of Agriculture's Foreign Agricultural Service (office at the U.S. Embassy in San Jose.

In general, the most favorable prospects continue to be bulk commodities (which represent roughly $63 \%$ of U.S. agricultural exports to Costa Rica), but the area of high value products continues to offer good market opportunities as well. Growing poultry and dairy industries are expected to continue to boost U.S. corn and soybean shipments, while a growing population, rising immigration, and stable incomes are expected to increase wheat and rice consumption and, thereby, U.S. export prospects. The trends toward consuming more convenience and healthy foods are expected to result in good prospects for U.S. exports of fresh fruit (mainly apples, grapes, peaches, and pears), processed fruits and vegetables 
(especially canned fruits), and snack foods (including chips, cookies and candies). However, some of those products are being negatively affected by imports at lower duties, mainly from Chile.

\section{Corn}

American corn export volume to Costa Rica increased $7 \%$ in 2002. The value of corn imports from all countries reached US\$59.9 million in 2002, up from US\$55.3 million in 2001. The United States had a $98.1 \%$ market share in 2002. Until 1997, all yellow corn was imported from the United States. Competition from other sources started in 1998. Imports of white corn have become an important component of total corn imports in recent years, as local production has declined relative to consumption.

The major expansion in the production of chicken meat and milk, along with smaller gains in output of swine meat and aquaculture, has fueled strong corn imports for feed. Meanwhile, domestic (white) corn production has been affected by negative weather conditions during the last couple of years, resulting in low returns. Two private sector groups continue to import almost all the yellow corn, while one company imports the majority of the white corn.

\section{Soybeans}

Total soybean imports totaled US $\$ 54.8$ million in 2002, as compared to US\$45.2 million in 2001, remaining in second place on the list of Costa Rica's largest agricultural import products in terms of value. Both import value and volume of soybeans increased during 2002. Based on preliminary data, imports were expected to increase during 2003 due to demand for larger feed volumes for local poultry and dairy industries. The United State lost its longstanding $100 \%$ share of the soybean import market in 1999 and 2000 (no soybeans are produced locally) due to competition from Brazil and Argentina. However, U.S. soybeans regained market share in 2001 and 2002, controlling almost $100 \%$ of the Costa Rican market. Soybeans are imported primarily for meal. Soybean oil has been in surplus over the last few years, with exports to Central America providing an outlet. There is only one oilseed crusher in Costa Rica
(INOLASA), located near the Pacific port of Caldera (where all bulk grains arrive).

\section{Wheat}

The value of wheat imports from the United States increased $23.5 \%$ to US\$30.4 million in 2002, up from US\$24.6 million in 2001. Import volume from all sources declined $2.9 \%$ during the same period; however, volume from the U.S. increased almost $18 \%$. In 2002, the United States regained some of the market share lost to Canada in previous years. About $75 \%$ of Costa Rican wheat imports are hard red spring, with soft red winter and durum comprising the rest. The United States traditionally supplied $100 \%$ of the market, but Canada is now serving this market as well. Canada exported 65,748 tons in 2000 to Costa Rica, 56,256 tons in 2001, and 34,057 tons in 2002 , or $16.8 \%$ of total imports. There are two wheat mills in Costa Rica: one that has continued importing mostly from the United States, and the other that has used Canadian wheat.

The private sector makes all wheat purchases. No wheat is produced locally. There is strong competition in the domestic market between the two local wheat mills: Molinos de Costa Rica (the largest) and FAHACASA.

\section{Rice}

After a shipment of 20,000 metric tonnes (MT) of rough rice from Uruguay in 1999, rice imports have been made primarily from the United States. Imports from the United States in 2002 amounted to 123,474 MT of rough rice (roughly 83,000 tons of milled rice equivalent), valued at US\$15.7 million. Import volume is expected to increase to $130,000 \mathrm{MT}$ and US\$17.0 million in 2003. The majority of rice imported by Costa Rica is rough rice. The GOCR has resorted to delaying the rice import process by holding sanitary permits for a longer than normal period of time. In addition, the GOCR charges US\$20 per metric tonne of imported rice for phytosanitary inspection. Rice is assessed a $35 \%$ duty and a price based safeguard that adds about $20 \%$, depending on price. The GOCR approved a law that allows only the rice sector to import rice duty free whenever a rice shortage is determined (normally every year during the first half of the year). 


\section{Fresh Fruit}

Costa Rican imports of fresh fruit reached a value of US\$27.4 million in 2002. Of total fresh fruit imports, $\$ 7.7$ million were imported from the United States. The leading fruit imports from the United States were grapes (US\$3 million), apples (US $\$ 3$ million), peaches (US\$689,000), and pears (US\$688,000). Total imports of fresh fruits from the United States declined during 2002, mainly as a result of higher imports from Chile (which now enjoys duty free access to the Costa Rican market for fruits competing with U.S. origin product).

The United States and Chile are exporting almost the same products to Costa Rica, but during different seasons. Imports from Chile take place from January to July. During the rest of the year, imports come mostly from the United States, except for those fruits available year round. Costa Rica imports fresh fruits year-round, but about $70 \%$ of total domestic consumption of non-tropical fruits occurs during the Christmas season (October through December).

The recent approval of a Costa Rica-Chile Free Trade Agreement (FTA) is already affecting U.S. competitiveness in this market, as competing fresh fruits from Chile now enjoy duty free access to Costa Rica. Costa Rica also signed a FTA with Canada, which entered into effect in November of 2002.

\section{Processed Fruits / Vegetables}

According to information from U.S. Customs, imports of U.S. processed fruit and vegetables totaled US\$8.3 million in 2002. These products, especially mixed fruits, mixed vegetables, yellow and sweet corn, peas, mushrooms, and garbanzo beans generate strong import demand. Mexico, Chile, and Guatemala are the main competitors of the United States in the Costa Rican canned fruit and vegetable market. The FTA with Chile has created more competition for the United States in these product categories. Based on preliminary data, the United States continued to lose market share in this sector during 2003.

\section{Snack Foods}

American exports of snack foods to Costa Rica totaled US\$8.5 million in 2001 and US $\$ 8$ million in 2002 , almost a $12 \%$ increase.
Imports of snack foods from the United States were expected to grow in 2003, based consumer demand for a wider variety of imported products.

The United States is facing increased competition in this sector as a result of free trade agreements signed with Chile, Canada, and Mexico. Prospects for U.S. exports in this sector may improve depending on the outcome of the CAFTA. Competing products are imported mainly from Central America (Guatemala and El Salvador) and from Chile, Argentina, and Europe on a smaller scale.

Domestic production of potato chips, chocolates and other candies, and cookies also provides competition for the United States. These products are also exported to Central America (with a small amount shipped to the United States).

\section{Trade Regulations and Standards}

\section{Trade Barriers}

There are no significant trade barriers affecting the entry of most goods and services into Costa Rica. It continues to unify and lower its tariffs in compliance with its commitments to its Central American neighbors and its WTO obligations. Costa Rica is a member of the so-called Cairns Group of agricultural free traders, but this position has its detractors within Costa Rica's agricultural sector. Opponents of free agricultural trade have attempted to block imports of some domestically-sensitive items (e.g., rice, potatoes, and onions).

The government of Costa Rica agreed in the Uruguay Round of trade negotiations to eliminate all import quotas and to reduce tariffs progressively. The current maximum tariff is $52 \%$ on most goods, excluding selected agricultural commodities of substantial local interest that are protected or "safeguarded" with significantly higher tariffs. Tariffs on safeguarded products are to be reduced over time. However, there are numerous examples of tariff protection in Costa Rica. One example of such protection is poultry products (currently with a $150 \%$ tariff) and dairy products (currently with a $65 \%$ tariff). Furthermore, at this time, pork imports from the United States are curtailed, pending an inspection 
and approval process from the Costa Rican Ministry of Agriculture.

\section{Customs Valuations}

Costa Rican Customs procedures are complex and bureaucratic, but they have improved somewhat since the passage of the 1995 General Customs Law. Much of the necessary processing is now accomplished electronically, and "one-stop" import and export windows have significantly reduced the time required for Customs processing.

Costa Rica generally does not require any special documentation for the entry of goods other than commercial invoices, bills of lading, and airway bills. Bulk agricultural products require phytosanitary certificates. Imports of cosmetics, chemicals, toxic substances, insecticides, pesticides, and agricultural chemicals require an import permit from the Costa Rican Ministry of Health. The permit can be obtained on presentation and approval of quantitative-qualitative analysis certificates and free-sale certificates, which must be provided by the exporter. A Costa Rican consul in the United States or other country of origin must authenticate these certificates.

Violations of documentation laws carry heavy fines. Consequently, great care must be taken to avoid errors and infractions. Questions pertaining to Customs issues should be addressed to the Costa Rican Customs Office: Dirección General de Aduanas, Calle 1, entre Avenidas 1 y 3, San Jose, Costa Rica (telephone 506-257-6202 or 506-233-9525; fax 506-223-7334).

Information on Free Trade Zones and the Active Finishing Regime, as well as statistical information on Costa Rican trade and listings of importers and exporters, is available from the Costa Rican Foreign Trade Corporation (PROCOMER), an autonomous agency headed by the Minister of Foreign Trade.

Applied Customs duties range typically from $1 \%$ to $15 \%$ ad valorem. The lowering of tariffs in recent years has been an important factor behind the growth of imports of consumer goods from the United States
Duties on imported raw materials, bulk grains, and oilseeds have been $1 \%$ since 1996 . Periodically Costa Rica reduces the applied tariff on rough rice and beans to meet local demand.

A $13 \%$ value-added (sales) tax is paid on most goods and services, including imported goods, not destined for official use by central or local governments. Certain basic products (staple foods, school uniforms, etc.) are exempted.

Selective consumption (excise) taxes for many imported (and domestic) products have been reduced or eliminated. However, excise taxes, ranging from $5 \%$ to $75 \%$, apply to about half of all products imported.

Some imports are also subject to Central Bank surcharges, generally also paid on goods manufactured in Costa Rica or in the rest of Central America, unless purchased by the Central Government or Municipalities, and are consequently tax exempt.

A 1\% surcharge is imposed on most imports, except medicines and raw materials for human consumption and industry.

\section{Standards}

Costa Rican law requires the exclusive use of the metric system but, in practice, accepts U.S. and European commercial and product standards. A "system of standards" has not been implemented in Costa Rica due to a lack of adequate laboratory equipment and funding. In some cases, U.S. and domestic companies doing business in Costa Rica use the ISO (International Standards Organization) designation in their promotional campaigns. As of January of 2002, 30 companies have been granted the ISO 14001 certification for environmental responsibility, along with included banana producers, hotel operators in ecologically sensitive areas, and other agrobusinesses.

\section{Labeling Requirements}

There are no general requirements in Costa Rica for marking the origin of general merchandise. However, Costa Rican food labeling regulations follow the Codex Alimentarius and require that all 
domestic and imported food products contain labeling in Spanish with the following specifications: product name, list of ingredients in quantitative order, nutritional content, name, and address of importer, expiration or best-used-by date, and metric weight.

Special labeling requirements apply to pharmaceuticals, fertilizers, pesticides, hormones, veterinary preparations, vaccines, poisonous substances, and mouthwashes.

Phytosanitary (USDA/APHIS) certificates are required for importing bulk grain and horticultural products. Zoosanitary (USDA/FSIS) certificates are required for importing fresh and frozen meats. Most processed food products (canned, boxed, and pre-cooked) do not require phytosanitary or zoosanitary certificates, but exporters should check with their importers, who are ultimately responsible for knowing local regulations.

\section{Temporary Entry Provisions}

Temporary entry of raw materials; intermediate products; components used in goods destined for export; and the machinery, equipment, spare parts, and tools used to produce the exported goods are available for firms registered to operate within a free trade zone or under the "Regime of Active Finishing". Under the free trade zone statutes, the government does not consider the imported goods to have entered Costa Rican Customs territory. Under the Regime of Active Finishing, duties on inputs for goods to be exported are suspended for six months for materials and components and five years for equipment, tools, and parts. These terms can be renewed. Either regime is available to foreign or domestic investors on application to the Ministry of Foreign Trade.

\section{Import Controls}

Food products require registration when imported for the first time. The Ministry of Agriculture requires phytosanitary and animal health certificates.Costa Rican importer must obtain the permits.

\section{Export Controls}

The registration of Costa Rican exports with the Central Bank allows the government to maintain export controls on some items, particularly if the goods are subsidized, under price controls, or intended for consumption by lower-income groups (rice, beans, sugar, etc.). Exports of livestock, wood, and ornamental plants require a license from the Ministry of Agriculture. Coffee exports are regulated by ICAFE (the National Coffee Institute). Sugar exports are regulated by LAICA (a producer's organization). Coffee, sugar, banana, and beef producers' organizations also allocate export amounts among the producers, up to the limit of various country quotas.

\section{Free Trade Zones / Warehouses}

Free Trade Zones and the Regime of Active Finishing are the only export incentive systems remaining in Costa Rica.

The Export Processing Law of 1981 established publicly operated Free Trade Zone (FTZ) industrial parks in Santa Rosa (Puntarenas) on the Pacific Coast and in Moin (Limon) on the Caribbean seaboard. Today, eight FTZs operate in Costa Rica, six of which are privately managed. The newest FTZ (opened in 1998) is in rural Turrialba. The benefits extended to qualifying companies established in FTZs include the following:

- $100 \%$ exemption from all import taxes associated with the import of goods used to make exported products. The same exemption is granted for the equipment and machinery used in the productive process.

- $100 \%$ exemption from sales and consumer taxes, and taxes levied on remittances abroad.

- $100 \%$ exemption from income tax for the first eight years of operations and 50\% exemption for the following four years for free zone investments in areas of "greater relative development".

- $50 \%$ longer periods of exemption from income taxes for free zone investments in areas of "lesser relative development". 
- credit for job creation in rural areas.

In addition to these benefits, companies operating in FTZs enjoy simplified investment, trade, and Customs procedures.

Subsequent to DOHA negotiations in 2001, the active finishing regime benefits were extended until 2007. These benefits provide for temporary admission and suspension of duty collection for material and equipment used to produce goods that are subsequently exported. There are no income tax benefits.

\section{Membership in Free Trade Agreements}

Costa Rica has reduced most tariff rates for imported goods to $15 \%$ or lower in unison with its Central American neighbors. Costa Rica has signed Free Trade Agreements with Canada, Mexico, the Central American Common Market, the Dominican Republic, Trinidad and Tobago, and Chile. The agreement with Canada has to be ratified by both countries. A similar trade agreement is being negotiated with Panama.

Costa Rica plays an active role in the negotiation of the Free Trade Area of the Americas (FTAA), a hemispheric agreement that is targeted for implementation by 2005. It is a founding member of the WTO.

Costa Rica is negotiating a free trade agreement with the United States as part of the CAFTA initiative during 2003.

\section{Investment Climate in Brief}

- Costa Rica has a generally open international trade and investment regime, with the exception of a few sectors that are reserved for state companies. The investment requirements for foreign and national persons and companies are identical.

- There are no restrictions on receiving, holding, or transferring foreign exchange. There are no delays for foreign exchange, which is readily available at market clearing rates and transferable through the banking system.
- Expropriation of private land by the government without prompt or adequate compensation has hurt Costa Rican and foreign investors in the past. These incidents usually involved land expropriated to create national parks, indigenous reserves, or agricultural projects for poor farmers.

- Costa Rica uses civil or statutory law rather than common law. Litigation can be long and costly. The legal system is significantly backlogged, and civil suits take over five years, on average, from start to finish.

- All private entities and persons, domestic or foreign, may establish and own businesses and engage in all but a few forms of remunerative activity. The exceptions are in sectors that are reserved for the state (legal monopolies) or that require participation of at least a certain percentage of Costa Rican citizens or residents (electrical power, broadcasting, professional services, and wholesale distribution).

- Secured interests in both chattel and real property are recognized and enforced, and mortgage and title recording is mandatory. The laws governing investments in land, buildings, and mortgages are generally transparent. However, there are continuing problems of overlapping titles to real property and fraudulent filings with the National Registry.

- Costa Rican laws, regulations, and practices are generally transparent and foster competition, except in monopoly sectors where competition is explicitly excluded.

- Bureaucratic procedures are frequently long, involved, and discouraging to new investors.

- There are no controls on capital flows in or out of Costa Rica or on portfolio investment in publicly traded companies.

- Costa Rica has laws, regulations, and penalties to combat corruption, though the resources available to enforce those laws are limited. Several cases of alleged corruption are under investigation or are being prosecuted. 
- The Costa Rican labor force is relatively well educated, skilled, and easily trained, largely due to long-term government investment in public education. The demand for English-language speakers is such that foreign investors have recently been facing a shortage of workers with sufficient English language skills.

\section{Business Customs}

\section{Travel Advisory and Visas}

A valid passport is required to enter Costa Rica. In March of 2004, the departure tax will increase from $\$ 17$ to $\$ 26$ for short-term visitors. Tourists who stay over 90 days without receiving a formal extension can expect to pay a higher departure tax at the airport or land border. Persons who have overstayed previous visas may be denied entry to Costa Rica. A surcharge, called a passenger facility fee, of $\$ 6.00$ is included in airline tickets. If the airline has not included this charge, then the traveler can pay it at the ticket counter.

Crime is increasing and tourists are frequent victims. While most crimes are non-violent, criminals, including juveniles, have shown a greater tendency in recent years to use violence. American citizens are encouraged to use the same level of caution they would exercise in major cities or tourist areas throughout the world.

The loss or theft abroad of a U.S. passport should be reported immediately to the local police and the nearest U.S. Embassy or Consulate. Travelers should carry a copy of their passport data page and leave the passport itself in the hotel safe or other secure location. Several tourists have landed in jail as a result of not carrying proper documents.

\section{Business Infrastructure}

Costa Rican business executives place great importance on personal contact with foreign suppliers. Appointments should take place in the host's facilities instead of hotel rooms, unless a special room has been arranged for the meeting. A business suit is appropriate for most business meetings.
Typical working hours are 8:00 a.m. to 6:00 p.m., with a two-hour lunch break between 12:00 p.m. and 2:00 p.m. The Costa Rican government has a continuous working schedule 7:30 a.m. to 4:00 p.m. Most banks are open 9:00 a.m. to 3:00 p.m.

Although Costa Rica's infrastructure is better than most in the region, its road system is not well maintained, causing strain to both vehicle and driver. Some roads are unusable without a four-wheel drive vehicle. Signage is poor and sometimes confusing. Outside of downtown San Jose, few areas have formal addresses. Costa Rica has more than 500 kilometers (300 miles) of railway track, but little of it is currently in use. All overland cargo, except bananas from the Pacific ports, is transported via truck.

Twenty international passenger airlines and fifteen cargo airlines serve San Jose's principal airport (Juan Santamaría International). To serve the Guanacaste beach area, the Liberia International Airport was inaugurated in December of 1991 and became fully operational in 1995 . There is good taxi and public bus service in the capital city of San Jose. Official taxis are red and are the recommended means of travel for business visitors. The official taxis have the name of the taxi company written on a yellow box on the top of the car. Car rental service is also available.

Costa Rica's telecommunications network is suffering from lack of investment. ICE (Instituto Costariccense de Electricidad) is the monopoly provider of telecommunications, Internet, and electricity services. The network has been plagued by constant failures since its inception. Internet connectivity is poor and extremely slow. Telephone service, in general, is reliable and public phones accept coins or local phone cards. The country also enjoys both public cellular services and data transmission services. For wireless users, Costa Rica has not signed a roaming agreement.

Costa Rica offers foreign business travelers a wide variety of suitable, modern hotels and excellent bed and breakfast facilities in San Jose and in neighboring cities. Prices are high for the region (US\$120 to US\$150 at larger hotels and US\$75 to 
US $\$ 100$ at medium hotels). Traditional business services are available in larger hotels.

In general, medical services are good. Many doctors in both the national health system and private clinics have been trained abroad and are fluent in English. Specialists are available in almost all branches of medicine. The Embassy maintains a list of specialized medical practitioners in case of emergencies. In areas outside of San Jose, medical care is more limited. Doctors and hospitals often expect immediate cash payment for health services. American medical insurance is not always valid outside the United States.

\section{Useful Web Sites}

\section{COSTA RICA:}

- Investor's Manual: Establishing a Business Enterprise in Costa Rica http://www.tramites.go.cr/manual/english/ default.htm

- Costa Rican Coalition for Development Initiatives (CINDE) http://www.cinde.or.cr

- Costa Rican Foreign Trade Corporation (PROCOMER) http://www.procomer.com

- Costa Rican-American Chamber of Commerce (AmCham) http://amcham.co.cr

- Costa Rican Ministry of Agriculture http://www.mag.go.cr

\section{UNITED STATES:}

- USDA Foreign Agricultural Service http://www.fas.usda.gov

- US Export Programs Guide http://infoserv2.ita.doc.gov/ticwebsite/tic.nsf/ AF34FA880278BDD5825690D00656C6F/ F69FDCF72B7713B58525691900746F18?Open Document

- Internet Guide to Trade Leads http://infoserv2.ita.doc/gov/ticwebsite/tic.nsf/ 504ca249c786e20f85256284006da7ab/ ef7db94aef24919885266470049c1cd?OpenDocu ment
- US Trade Finance Resources http://infoserv2.ita.doc.gov/ticwebsite/tic.nsf/ AF34FA880278BDD5825690D00656C6F/ F69FDCF72B7713B58525691900746F18?Open

Document

- Basic Guide to Exporting http://www.unzco.com/basicguide/index.html

\section{HEMISPHERIC:}

- Hemispheric Guide on Customs Procedures http://alca-ftaa.iadb.org/hgcp_eng.htm

- Hemispheric Trade and Tariff Database http://alca-ftaa.iadb.org/eng/ngmadb_e.htm 